Reprod. Nutr. Dévelop., 1981, 21 (5A), 651-659.

\title{
Effect of various modifications in the diet on ileal epithelium renewal in germ-free and conventional rats
}

\author{
par J. C. MESLIN, E. SACQUET*, M. RIOTTOT * \\ with the technical assistance of Michèle SEREZAT \\ Station de Recherches de Nutrition, I.N.R.A., \\ 78350 jouy en Josas, France. \\ * Laboratoire des animaux sans germes, C.N.R.S., I.N.R.A., \\ 78350 jouy en Josas, France.
}

Summary. Renewal of the ileal epithelium has been studied in germ-free (GF) and conventional $(\mathrm{CV})$ rats fed with a semi-synthetic diet in the following forms : a) pellets sterilized by autoclaving (Pel. Au. diet) ; b) powder sterilized by gamma irradiation ; when given to the rats, its weight in water was added to make a paste (Pa. I. dief) ; c) powder treated as (b) but with 10 p. 100 lactose added (L. Pa. I. diet).

Ileal epithelium renewal time was similar in the GF rats fed with the Pel. Au. and Pa. I. diets. It was shorter in the CV rats fed with these two diets than in the GF rats and also in the $\mathrm{CV}$ rats given the $\mathrm{Pa}$. I. diet than in those given the Pel. Au. diet.

In GF and CV rats fed with the lactose diet, L. Pa. I., ileal epithelium renewal time was similar.

These different effects were mainly due to variations in the number of cells produced in Lieberkühn's crypts. They were not related to changes in the intestinal bile salts pool caused by the different diet treatments.

\section{Introduction.}

Intestinal epithelium renewal is modified by many factors. The presence of a microbial flora accelerates epithelial renewal (Guenet et al., 1970 ; Galjaard et al., 1972 ; Meslin, Sacquet and Raibaud, 1974). When the bile by-passes the small intestine, renewal is accelerated in germ-free (GF) ${ }^{1}$ ) but not in conventional (CV) ${ }^{1}$ ) rats (Meslin ef al., 1978). As the ileum is the privileged site for bile salts absorption, and as the intestinal bile salts pool is two to three times larger in GF than in CV rats, it was thought that there might be a relation between bile salts (BS) pool size and ileal epithelium renewal.

Recent studies (Sacquet, Leprince and Riottot, 1979 ; Riottot, Sacquet and Leprince, 1980) have shown that simple changes in the diet cause the intestinal BS pool to vary widely in GF and $C V$ rats. We wished to determine if such changes in the diet would cause variations in ileal epithelium renewal.

(1) Germ-free = axenic ; conventional = holoxenic. 


\section{Material and methods.}

Animals. - GF and CV inbred male Fisher rats were fed with the experimental diets ad libitum for one month before the experiment. They were 4 months old when the experiment began.

Diets. - The basic diet contained $200 \mathrm{~g}$ of casein, $580 \mathrm{~g}$ of cornstarch, $90 \mathrm{~g}$ of cornoil, $50 \mathrm{~g}$ of cellulose, $45 \mathrm{~g}$ of a mineral-vitamin mixture. This diet was treated in three different ways :

1) Pelleted, autoclaved (Pel. Au.) : mixed with $200 \mathrm{~g}$ of water $/ \mathrm{kg}$, then pelleted and autoclaved at $120^{\circ} \mathrm{C}$ for $20 \mathrm{~min}$ (called SNAU in previous studies).

2) Paste, irradiated (Pa. I.) : powder irradiated at 40 kilograys (4 megarads) and mixed with its weight in water when given to the rats.

3) Lactose, paste, irradiated (L. Pa. I.) : same as (2) but with 10 p. 100 lactose added.

Study of ileal epithelium renewal. - The rats were given an intraperitoneal injection of $0.3 \mathrm{mCl}$ of tritiated thymidine $(1 \mu \mathrm{Ci} / \mathrm{g}, \mathrm{SA} 1 \mathrm{Ci} / \mathrm{mM})$. Part of the data on the Pel. Au. diet, taken from a previous experiment (Meslin et al., 1978), were completed by counting the labelled enterocytes $1 \mathrm{hr}$ after the marker was injected. Eight, 27 and $41 \mathrm{hrs}$ were chosen for the GF and CV rats given the Pa. I. diet as well as $1 \mathrm{hr}$ for the CV rats. GF and CV rats given the L. Pa. I. diet were studied 1, 27 and 41 hrs after tritiated thymidine injection. The intestines were fixed using techniques which have been already described (Guenet ef al., 1970 ; Meslin et al., 1973, 1974).

At various times after the tritiated thymidine injection, we counted the number of enterocytes from the base of the crypt to the top of the villus, and we distinguished three compartments : crypt, villus and the compartment extending from the base of the crypt to the farthest labelled cells. For the sake of simplicity, this compartment was called compartment of labelled cells. Cellular production per column over a 24 hrs period was computed from the changes in the labelled enterocytes at various time intervals. At least 10 columns per rat were counted. Ileal epithelium renewal time was the time needed for the labelled enterocytes to reach the top of the villi, calculated from the leading edge of labelling at various times.

Statistical analysis. - The results are expressed by the arithmetic mean of the values observed $\pm \mathrm{SEM}$. Their significance was defermined using the multiple mean comparison method of Newman and Keuls (Newman-Keuls multiple range test : Newman, 1939 ; Keuls, 1952) modified by Duncan (1955) and extended to group means with unequal numbers of replication (Kramer, 1956).

\section{Results.}

Table 1 shows the number of enterocytes in the crypts and villi and their overall number in GF and CV rats given the Pel. Au., Pa. I. and L. Pa. I. diets.

As compared to the Pel. Au. diet, the Pa. I. diet slightly increased the number of crypt cells in GF and CV rats. It augmented the number of villus enterocytes only in GF 
TABLE 1

Number of epithelial cells in crypts, villi and crypts + villi in the ileum in Gv and CV rats fed with Pel. Au., Pa. I. or L. Pa. I. diets (mean \pm SEM ; $n=$ number of rats)

\begin{tabular}{|c|c|c|c|c|}
\hline & $\mathrm{n}$ & Crypts & Villi & Crypis + villi \\
\hline $\begin{array}{l}\text { GF Pel. Au. } \ldots \ldots \ldots \\
\text { CV Pel. Au. } \ldots \ldots \ldots \\
\text { GF Pa. I. } \ldots \ldots \ldots \ldots \\
\text { CV Pa. I. } \ldots \ldots \ldots \ldots \\
\text { GF L. Pa. I. } \ldots \ldots \ldots \\
\text { CV L. Pa. I. } \ldots \ldots\end{array}$ & $\begin{array}{r}21 \\
25 \\
8 \\
8 \\
18 \\
21\end{array}$ & $\begin{array}{l}20 \pm 0.12(\mathrm{a}) \\
21.4 \pm 0.22(\mathrm{~b}) \\
21.1 \pm 0.29 \text { (b) } \\
23.8 \pm 0.59 \text { (c) } \\
20.3 \pm 0.26(\mathrm{a}) \\
21.5 \pm 0.21 \text { (b) }\end{array}$ & $\begin{array}{l}43.6 \pm 1.3(\mathrm{a}) \\
48.6 \pm 0.8(\mathrm{~b}) \\
47.8 \pm 0.9 \text { (b) } \\
47.5 \pm 2(\mathrm{a}, \mathrm{b}) \\
61 \pm 2.7(\mathrm{~d}) \\
54.2 \pm 1.3(\mathrm{c})\end{array}$ & $\begin{array}{l}63.3 \pm 1.01(\mathrm{a}) \\
69.7 \pm 0.79(\mathrm{~b}) \\
69.2 \pm 0.88(\mathrm{~b}) \\
71.3 \pm 1.85(\mathrm{~b}) \\
81 \pm 4.34(\mathrm{c}) \\
75.6 \pm 1.50(\mathrm{~b}, \mathrm{c})\end{array}$ \\
\hline
\end{tabular}

Means not having the same letter are significantly different $(P<0.05)$, according to the NewmanKeuls multiple range test.

rats. The total number of enterocytes was lower in GF rats fed with the Pel. Au. diet and the same in the other experimental groups.

As compared to the Pa. I. diet, the L. Pa. I. diet decreased the number of crypt enterocytes but increased that in the villi. This augmentation was higher in GF than in CV rats.

Figures 1, 2 and 3 show the number of labelled cells at different experimental times in rats fed with the Pel. Au., Pa. I. and L. Pa. I. diets. Using these experimental points, we plotted lines showing labelled cell migration from the crypts to the top of the villi.

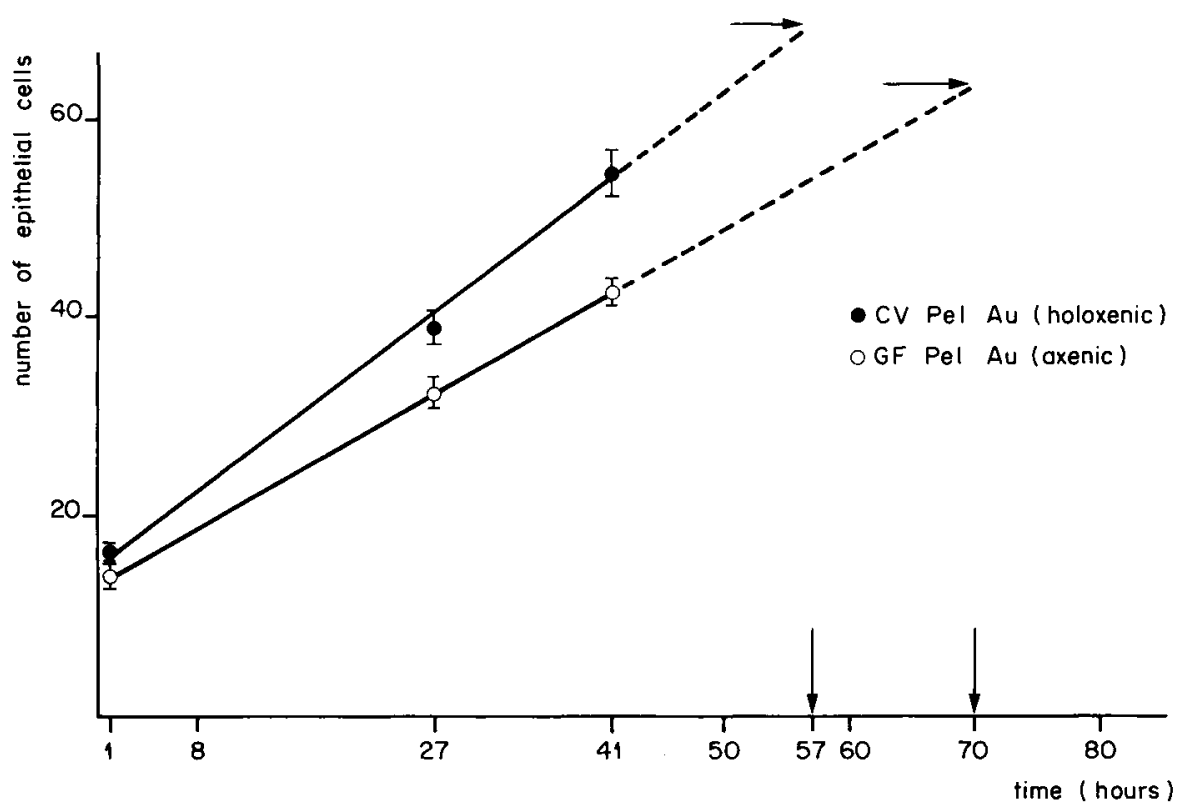

FIG. 1. - Migration of labelled epithelial cells in the ileum after tritiated thymidine administration (mean \pm confidence limit of the mean) in conventional and germ-free rats fed with an autoclaved dief. 
These lines, corresponding to the GF Pa. I. (fig. 2) and the GF Pel. Au. (fig. 1) groups overlap. On the contrary, the slope of the line corresponding to the CV Pa. I. group (fig. 2) is steeper than of the CV Pel. Au. group (fig. 1) so that the difference between GF and $C V$ rats seems greater in the first case than in the second. In both cases, the lines of the GF rats fall below those of the CV rats and are not as sleep.

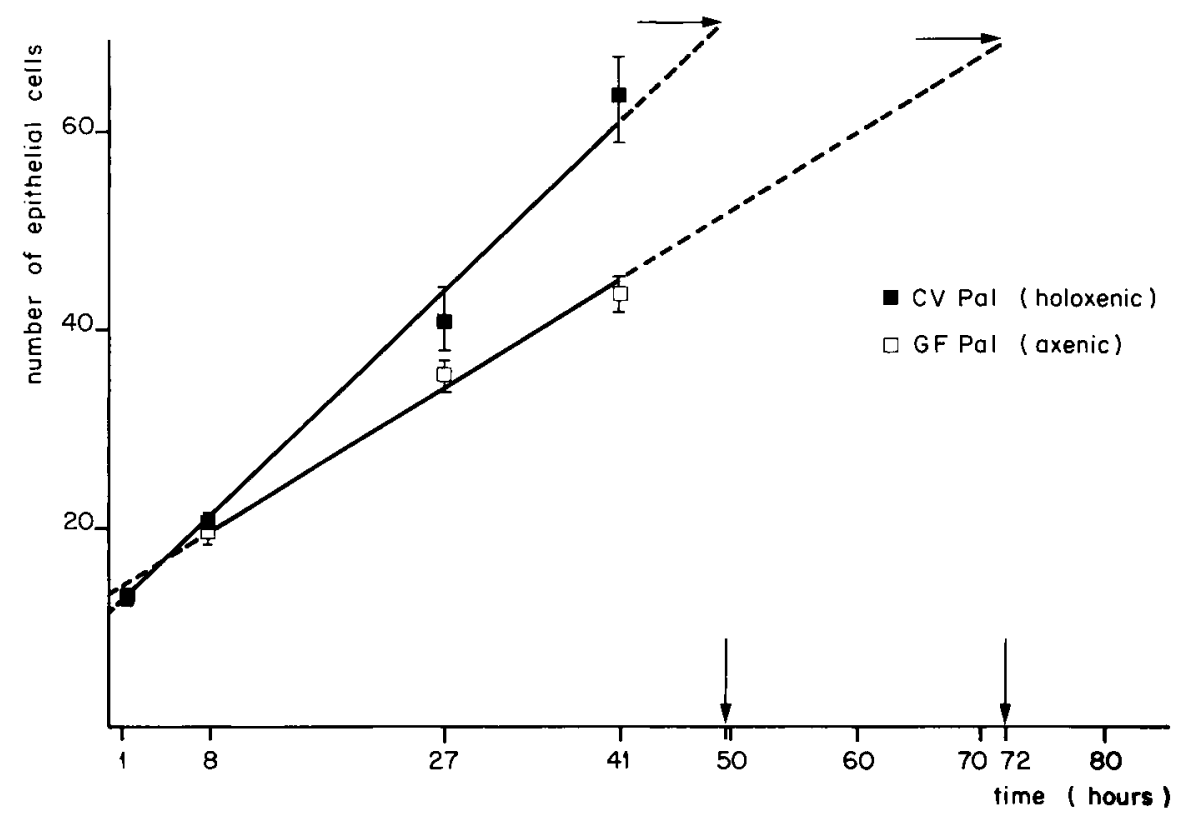

FIG. 2. - Migration of labelled epithelial cells in the ileum after tritiated thymidine administration (mean $\neq$ confidence limit of the mean) in conventional and germ-free rats fed with an irradiated dief.

The results on rats fed with the L. Pa. I. diet (fig. 3) are different. All the GF values and thus the GF rat line, are higher than the corresponding values for $C V$ rats. The slopes of these two lines show very little difference.

Using these experimental results, we calculated the characteristics of epithelial renewal shown in table 2 . The intersection of the line with the $y$-axis, or the regression line constant, gives the number of cells in S-phase at zero time. This number varied little among GF Pel. Au., GF Pa. I. and GF L. Pa. I. rats. On the contrary, it varied considerably in the $\mathrm{CV}$ rats fed with the various diets, the lowest value being found in CV L. Pa. I. rats.

The slope of the different lines depended on cellular production per colum $P$ (table 2) in Lieberkühn's crypts which was not different in GF Pel. Au and Pa. I. rats. It was higher in CV than in GF rats and also in CV Pa. I. than in CV Pel. Au. animals. The presence of lactose increased cellular production considerably in GF rats, while this production was not equal to that in CV Pa. I. animals and decreased in CV rats.

Epithelium renewal time $T$ was defined by the intersection of labelled cell migration lines and the $y$-values corresponding to the total number of epithelial cells. In spite 


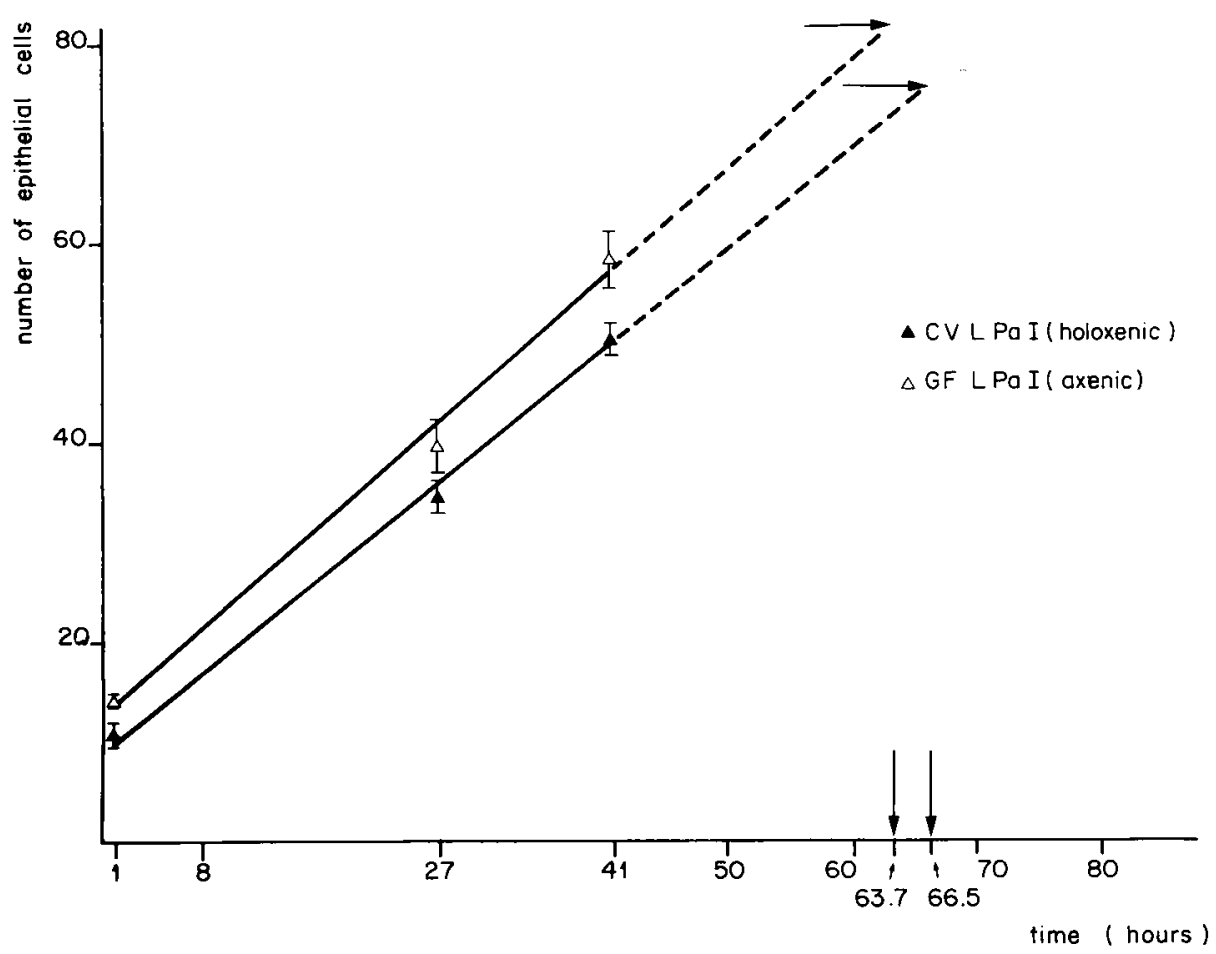

FIG. 3. - Migration of labelled epithelial cells in the ileum ofter tritiated thymidine administration (mean \pm confidence limit of the mean) in conventional and germ-free rats fed with an irradioted diet with 10 p. 100 lactose.

\section{TABLE 2}

Cell production per column $/ 24 \mathrm{hrs,}$, renewal time (hrs), regression line and deferminotion coefficient in the ileum in GF and $\mathrm{CV}$ rats fed with Pel. Au. Pa. I. or L. Pa. I. diets

(mean $\pm S E M ; n=$ pooled data at different times after labelling with tritiated thymidine)

n $\begin{gathered}P=\text { cell } \\ \text { production } / 24 \mathrm{hrs}\end{gathered} \quad \begin{gathered}T=\text { renewal } \\ \text { time (hrs) }\end{gathered} \quad$ Regression line $\quad \begin{gathered}\text { Defermination } \\ \text { coefficient }\left(r^{2}\right)\end{gathered}$

$\begin{array}{lrllll}\text { GF Pel. Au.. } & 127 & 17 \pm 0.3(\mathrm{a}) & 69.8 \pm 1.3(\mathrm{~d}) & y=0.71 t+13.9 & 0.93 \\ \text { CV Pel. Au. } & 109 & 22.6 \pm 0.4(\mathrm{~b}) & 57.2 \pm 1.2(\mathrm{~b}) & y=0.94 t+15.8 & 0.91 \\ \text { GF Pa. I. .. } & 38 & 18.6 \pm 0.4(\mathrm{a}) & 71.8 \pm 1 \text { (d) } & y=0.77 t+13.3 & 0.94 \\ \text { CV Pa. I. . } & 82 & 29 \pm 0.3(\mathrm{e}) & 49.5 \pm 0.9(\mathrm{a}) & y=1.20 t+11.4 & 0.96 \\ \text { GF L. Pa. I. } & 144 & 26.1 \pm 0.4 \text { (d) } & 63.7 \pm 1.4(\mathrm{c}) & y=1.1 t+12.6 & 0.92 \\ \text { CV L. Pa.I. . } & 144 & 23.9 \pm 0.3 \text { (c) } & 66.7 \pm 0.8(\mathrm{c}, \mathrm{d}) & y=1 \quad t+9.1 & 0.95\end{array}$

Means not having the same letter are significantly different $(P<0.05)$, according to the NewmanKeuls multiple range test. 
of variations in the latter number, the $T$ values were arranged inversely to $P$. The epithelial renewal time was similar in GF Pel. Au. and Pa. I. rats. It was shorter in CV rats fed with these two diets than in GF rats, and also in those fed with the Pa. I. than the Pel. Au. diet. Ileal epithelium renewal time was similar in GF and CV animals receiving the L. Pa. I. diet.

\section{Discussion.}

A study of intestinal epithelium renewal is difficult. Tritiated thymidine labelling and enterocyte counting seem to be the most efficient method. The experimental points obtained are not strictly aligned, particularly those of the CV Pa. I. group. Therefore, in spite of the large number of observations, these results must be cautiously interpreted. Less difficult methods are more frequently employed, i.e. determination of the number of labelled cells 30 min or $1 \mathrm{hr}$ after tritiated thymidine injection (Stragand and Hagemann, 1977 ; Pansu, Bellaton and Bosshard, 1978 ; Cohen et al., 1980). Figure 2, or the particularly low values in the CV L. Pa. I. group in figure 3, demonstrate the uncertainty of this method which labels the cells in S-phase. The number of labelled cells depending on the number of stem cells and the relative length of the S-phase in relation to the length of the cell cycle, cellular production may not be expressed. The present study shows that changes in the diet affect the number of cells in S-phase in CV rats, as in the mouse colon (Stragand and Hagemann, 1977). In the GF rats, the variations of the number of cells in S-phase are smaller. Labelling index, i.e. mean number of cells in S-phase versus mean number of cells in the crypt, is considerably low in CV Pa. I. and CVL. Pa. I. rats. It is not known how the Pa. I. treatment of the diet acts on this labelling index.

In spite of the technical difficulties of this type of study, it seems that simple, and apparently minor, changes in the diet may cause variation in (i) the number of cells in S-phase, (ii) the number of ileal epithelium cells, (iii) cellular production per column. Lactose ( $\mathrm{L}$. Pa. I. diet) had the clearest effect. As sterilization was carried out by gamma rays on dry feed under vacuum, it caused minimal alteration (Bayle, 1969 ; Coates ef al., 1969 ; Hiller and Schoen, 1971). It is thus probable that the L. Pa. I. and Pa. I. diets only differed by the presence or absence of a relatively small amount of lactose (10 p. 100). The effect on ileal epithelium renewal however was spectacular and had the opposite effect from that of the bacterial flora.

This result leads to several considerations. The bile salt pools have been determined in previous experiments carried out on rats of the same origin fed the same diets as in the present experiments. Assuming that the values are identical in the rats of the previous experiments and the present one, there is no relation between the intestine BS pool and ileal epithelium renewal (fig. 4). Lactose, which did not affect this pool modified $T$ considerably. The explanation for the variations of $T$, in relation to the flora and the diet, is therefore not a simple one. Lactose may be added to the list of T-variation factors (Pansu, Berard and Lambert, 1977) : total (hen : Cook and Bird, 1973 ; Rolls et al., 1975 ; mouse : Abrams ef al., 1963 ; Lesher et al., 1964 ; Khoury et al., 1969 ; Ranken, Wilson and Bealmer, 1971 ; Mastromarino and Wilson, 1976 ; rat : Guenet et al., 1970 ; Galjaard ef al., 1972 ; Meslin et al., 1974) or partial (Meslin, Sac- 


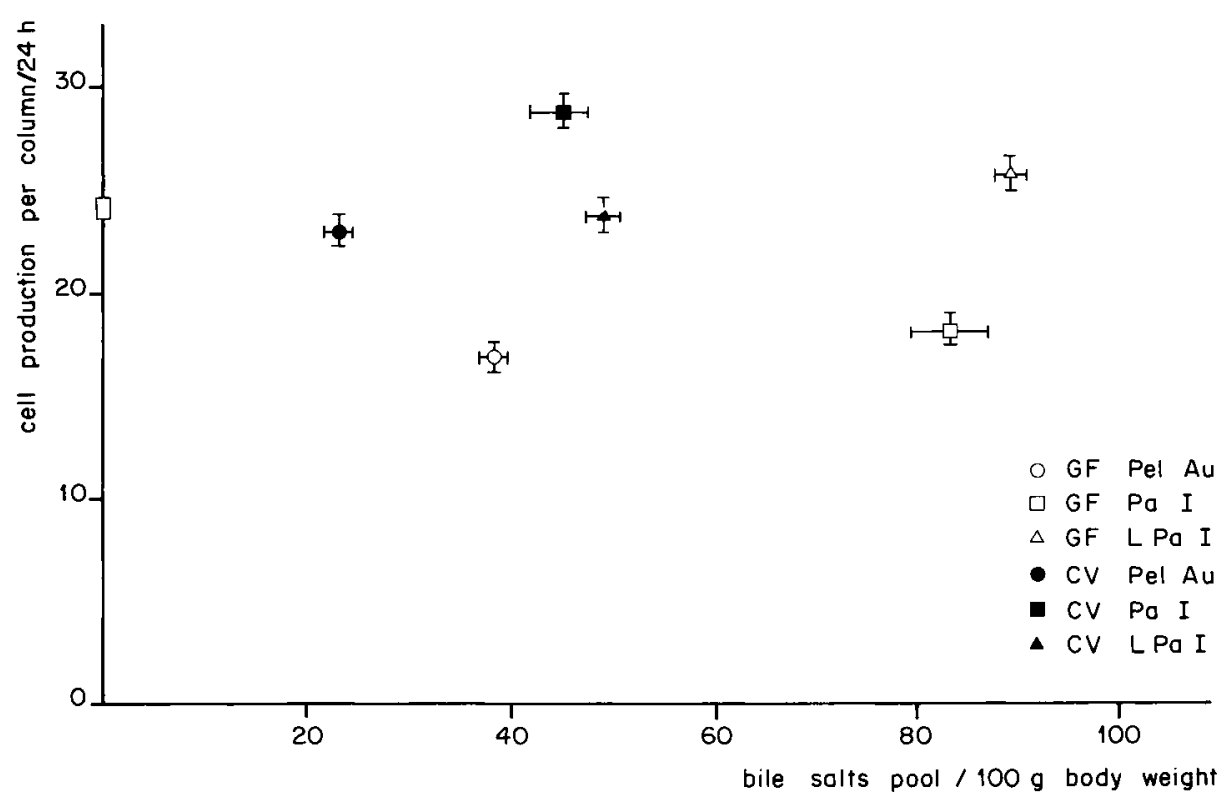

FIG. 4. - Relationship between cell production per column $/ 24$ hrs and the bile salts pool of the small infestine (mean $\pm S E M$ ) ; y-axis : aGF with bile by-pass (Meslin ef al., 1978).

quet and Raibaud, 1974) intestinal flora, sodium cholate (Ranken, Wilson and Bealmer, 1971 ; Mastromarino and Wilson, 1976) and bile by-pass (Roy et al., 1975 ; Meslin et al., 1978 ; Deschner and Raicht, 1979). No hypothesis can be proposed to explain how lactose acts on $T$. It is known that this substance is not entirely digested in the small intestine and that CV rat bacteria play an important role in its digestion and transformation into lactic acid and volatile fatty acids. Lactose also modifies the $\mathrm{CV}$ rat flora and its metabolic activities (Atkinson, Kratzer and Stewart, 1957 ; Kim, Benevenga and Grummer, 1978 ; Adrian and Frangne, 1978). Its presence in the dief improves the apparent absorption of many minerals, and this action differs in GF and CV rats (Andrieux, Guéguen and Sacquet, 1980). Lactose action on T, as its action on mineral metabolism, occurs in the ileum and differs in GF and CV rats. It is not at all clear how one of these actions could help to clarify the mechanism of the other. The methodical study of enterocyte physiology, which is just beginning, will probably have to be a great deal more advanced before the answer to these processes will be found.

Reçu en novembre 1980.

Accepté en mars 1981.

Acknowledgements. - We wish to thank Mr. J. P. Bouchet, Station de recherches de Nutrition, for aiding us with the statistical analysis and Ms. Alice Daifuku for editing the English manuscript. This study received a grant from the DGRST ( ${ }^{\circ} 77.70 .475$ «Interrelations Aliment-Tube digestif »). 
Résumé. Le renouvellement de l'épithélium iléal a été étudié chez des rats axéniques (GF, germfree) et holoxéniques (CV, conventional) qui étaient nourris d'un aliment semisynthétique selon les modalités suivantes : a) l'aliment était sous forme de pellet et stérilisé par autoclavage (aliment Pel. Au.) ; b) laissé sous forme de poudre, stérilisé par irradiation gamma, donné aux rats sous forme d'une pâte obtenue en lui ajoutant son poids d'eau (aliment Pa. I.) ; c) additionné de 10 p. 100 de lactose et traité comme en $b$ ) (aliment L. Pa. I.).

Chez les rats GF qui reçoivent les aliments $\mathrm{Pel}$. Au. et $\mathrm{Pa}$. I, le temps de renouvellement de l'épithélium iléal est semblable. Chez les rats $C V$ qui reçoivent ces deux aliments, il est plus court que chez les rats GF, et aussi plus court chez ceux qui reçoivent l'aliment Pa. I. que chez ceux qui reçoivent l'aliment Pel.' Au.

Chez les rats GF et CV qui reçoivent l'aliment laciosé, L. Pa. I, le temps de renouvellement de l'épithélium iléal devient semblable.

Ces différents effets sont principalement dus à des variations de la production cellulaire au niveau des cryptes de Lieberkühn. Ils ne sont pas en relation avec les modifications du pool intestinal des sels biliaires induites par ces différents traitements de l'aliment.

\section{References}

ABRAMS G. D., BAUER H., SPRINZ H., 1963 . Influence of the normal flora on mucosal morphology and cellular renewal in the ileum. A comparison of germ-free and conventional mice. Lab. Invest., 12, 355-364.

ADRIAN J., FRANGNE R., 1978. Rôle de la flore digestive dans l'adaptation du rat à une alimentation lactosée. Int. J. Vit. Nutr. Res., 48, 170-176.

ANDRIEUX Cl., GUÉGUEN L., SACQUET E., 1980. Effects of lactose and mode of sterilization of a lactose diet on mineral metabolism in germ-free and conventional rats. Reprod. Nutr. Dévelop., 20, 119-138.

ATKINSON R. L., KRATZER F. H., STEWART G. F., 1957. Lactose in animal and human feeding. J. Dairy Sci., 40, 1114-1132.

BAYLE G. L., 1969. Influence de la stérilisation gamma sur la valeur nutritive de lo caséine chez le rat. D. E. S., Clermont-Ferrand.

COATES M. E., FORD J. E., GREGORY M. E., THOMSON S. Y., $1969 . \quad$ Effects of gamma-irradiation on the vitamin content of diets for laboratory animals. Lab. Anim., 3, 39-49.

COHEN B. I., RAICHT R. F., DESCHNER E. E., TAKAHASHI M., SARVAL A. N., FAZZINI E., 1980. Effect of cholic acid feeding on $\mathrm{N}$-methyl-N-nitrosourea-induced colon tumors and cell kinetics in rats. J. nat. Cancer Inst., 64, 573-578.

COOK R. H., BIRD F. H., 1973. Duodenal villus area and epithelial cellular migration in conventional and germ-free chicks. Poultry Sci., 52, 2276-2280.

DESCHNER E. E., RAICHT R. F., 1979. Influence of bile on kinetic behavior of colonic epithelial cells of the rat. Digestion, 19, 322-327.

DUNCAN D. B., 1955. Multiple range and multiple $F$ tests. Biometrics, 11, 1-42.

GALIAARD H., VAN DER MEER-FIEGGEN W., GIESEN J., 1972. Feedback control by functional villus cells on cell proliferation and maturation in intestinal epithelium. Exp. Cell Res., 73, 197-207.

GUENET J. L., SACQUET E., GUENEAU G., MESLIN J. C., 1970. Action de la microflore totale du raf sur l'activité mitotique des cryples de Lieberkühn. C. R. Acad. Sci. Paris, Sér. D, 270, 3087-3090.

HILLER H. H., SCHOEN A., 1971. Einfluss fehlender Darmflora auf die Verdaulichkeit einer unterschiedlich sterilisierten Ratten und Mäusezuchtdiät bei Ratten. Z. Tierphysiol. Tierernährg. Futtermittel Kde., 28, 12-18.

KEULS M., 1952. The use of the studentized range in connection with an analysis of variance. Euphytica, 1, 112-122.

KHOURY K. A., FLOCH M. H., HERSH T., 1969. Small intestinal mucosal cell proliferation and bacterial flora in the conventionalisation of the germ-free mouse. J. exp. Med., 130, 659-670.

KIM K. I., BENEVENGA N. J., GRUMMER R. H., 1978. Estimation of the fraction of the lactose in a high lactose diet available for fermentation in the caecum and colon of the rat. J. Nutr., 108, 79-89. 
KRAMER C. Y., 1956. Extension of multiple range tests to group means with unequal numbers of replication. Biometrics, 12, 307-310.

LESHER S., WALBURG H. E., SACHER G. A., 1964. Generation cycle in the duodenal crypt cells of germ-free and conventional mice. Nature, 202, 884-886.

MASTROMARINO A. J., WILSON R., 1976. Increased intestinal mucosal turnover and radiosensitivity to supralethal whole-body irradiation resulting from cholic acid-induced alterations of the intestinal microecology of germfree CFW mice. Radiat. Res., 66, 393-400.

MESLIN J. C., SACQUET E., GUENET J. L., 1973. Action de la flore bactérienne sur la morphologie et la surface de la muqueuse de l'intestin grêle du rat. Ann. Biol. anim. Bioch. Biophys., 13, 203-214.

MESLIN J. C., SACQUET E., RAIBAUD P., 1974. Action d'une flore microbienne qui ne déconjugue pas les sels biliaires sur la morphologie et le renouvellement cellulaire de la muqueuse de l'intestin grêle du rat. Ann. Biol. anim. Bioch. Biophys., 14, 709-720.

MESLIN J. C., SACQUET E., RIOTTOT M., LÉGLISE P. C., 1978. Effet d'une dérivation de la bile hors du tractus digestif pendant une période prolongée, sur le renouvellement de l'épithélium iléal chez le rat axénique ef le rat holoxénique. Ann. Biol. anim. Bioch. Biophys., 18, 295-303.

NEWMAN D., 1939. The distribution of range in samples from a normal population expressed in terms of an independent estimate of standard deviation. Biometrika, 31, 20-30.

PANSU D., BELLATON C., BOSSHARD A., 1978. Effect of lactose feeding on cell renewal, disaccharidase activity and calcium-binding protein content in the intestinal mucosa of rats. Ann. Biol. anim. Bioch. Biophys., 18, 127-132.

PANSU D., BERARD A., LAMBERT R., 1977. Regulation du renouvellement cellulaire dans la muqueuse gastrointestinale. Poth. Biol., 25, 119.133.

RANKEN R., WILSON R., BEALMER P. M., 1971. Increased turnover of intestinal mucosal cells of germ-free mice induced by cholic acid. Proc. Soc, exp. Biol. Med., 138, 270-272.

ROLLS B. A., HEDGE S. N., TURVEY A., COATES M. E., 1975. Some characteristics of germfree and conventional chickens. Vth int. Symp. on Gnotobiology, Stockholm, 9-12 june 1975 (Abstr. $n^{\circ} 3$ ).

RIOTTOT M., SACQUET E., LEPRINCE C., 1980. Variations of bile salts pool size on secretion rate in rats according to the modes of sterilization and preparation of a semi-synthetic diet. Reprod. Nutr. Dévelop., 20, 1481-1488.

ROY C. C., LAURENDEAU G., DOYON G., CHARTRAND L., RIVEST M. R., 1975. The effect of bile and of sodium taurocholate on the epithelial cell dynamics of the rat small intestine. Proc. Soc. exp. Biol. Med., 149, 1000-1004.

SACQUET E., LEPRINCE C., RIOTTOT M., 1979. Effect of different modifications of a semi-synthetic diet on bile acid metabolism in axenic and holoxenic rats. Ann. Biol. anim. Bioch. Biophys., 19, 1677-1688.

STRAGAND J. J., HAGEMANN R. F., 1977. Dietary influence on colonic cell reneval. Am. J. clin. Nutr., 30, 918-923. 